\title{
PENDAMPINGAN OPERASIONAL MIKROSKOP DASAR DI SMA ISLAM AL AZHAR NW KAYANGAN
}

\author{
Nofisulastri $^{1}$, Siti Rabiatul Adawiyah ${ }^{1}$, Akhmad Haolani $^{2}$ \\ ${ }^{1}$ Dosen IKIP Mataram, ${ }^{2}$ Guru MA. Annajah Yayasan Al-Halimy \\ ${ }^{*}$ Korespondensi: nofisulastri@ikipmataram.ac.id
}

Diterima 18 Juni 2019 / Disetujui 20 Juli 2019

\begin{abstract}
ABSTRAK
Tujuan kegiatan pengabdian ini bertujuan untuk mengenalkan jenis mikroskop dasar dan peningkatan keterampilan peserta terhadap penggunaan operasional mikroskop dasar. Target kegiatan berupa transfer ilmu berupa pengenalan dan penggunaan mikroskop dasar sehingga peserta cakap cukup terampil dam pengoperasionalnya, serta mengenalkan berbagai macam bentuk sel dan jaringan makhluk hidup secara mikroskopis. Peserta kegiatan terdiri atas siswi kelas XII MA Annajah Yayasan Pendidikan Al-Halimy (12 orang), siswa-siswi SMA Islam Al Azhar NW Kayangan (10 orang), dan mahasiwa semester II FPMIPA IKIP Mataram sebanyak 25 orang. Kegiatan dilaksanakan mulai 10 sampai dengan 24 April 2019 bertempat Laboratorium Biologi FPMIPA IKIP Mataram. Tahapan kegiatan pengabdian kepada masyarakat ini terdiri atas diskusi dengan mitra (guru dan dosen pengampu matakuliah), Penayangan video promosi dan profil IKIP Mataram, Sosialisasi makhluk hidup secara mikroskopis dan operasional mikroskop dasar, simulasi penggunaan mikroskop dasar, pendampingan operasional mikroskop secara langsung, dan evaluasi respon kegiatan. Hasil rekapitulasi respon kegiatan menunjukkan bahwa ketertarikan terhadap kegiatan sebesar $97 \%$ berkategori menarik dan menyenangkan, kebermanfaatan ilmu senilai $90 \%$ dan ketertarikan untuk mengikuti kegiatan sejenis sebesar $98 \%$.
\end{abstract}

Kata kunci: pendampingan, mikroskop dasar

\section{PENDAHULUAN}

Hasil temuan observasi sekolah (lokasi calon binaan) menunjukkan bahwa guru bidang studi mata pelajaran IPA di sekolah MTs khususnya wilayah kabupaten Lombok Barat dan Lombok Utara masih memiliki permasalahan tersendiri dalam hal mata pelajaran dan praktikum yang diampu. Berdasarkan tuntutan kurikulum 2013 yaitu guru dituntut mampu menguasai ilmu pengetahuan di bidangnya dan terampil ketika melaksanakan kegiatan praktikum termasuk salah satunya menggunakan beberapa alat-alat yang ada di laboratorium. Permasalahan yang seringkali muncul yaitu dalam penggunaan alat-alat untuk kegiatan praktikum misalnya penggunaan mikroskop. Ketersediaan mikroskop diistilahkan hanya cukup sebagai pajangan atau cukup siswa mengetahui mikroskop, namun aplikatif yang teridentifikasi belum terlaksana secara maksimal.

Selain itu keterbatasan informasi dan pengetahuan yang dimiliki oleh guru mengenai pengenalan dan penggunaan mikroskop sesuai dengan standar operasional (SOP). Alhasil keterbatasan dan kurangnya kemampuan dalam mengoperasikan alat mikroskop dapat mengakibatkan mikroskop yang tesedia 
hanya sebatas memperkenalkan mikroskop secara umum sehingga menjadi masalah ketika kegiatan praktikum dilaksanakan tidak akan berjalan sesuai dengan harapan, maka perlu diberikan pemahaman dan keterampilan menggunakan alat mikroskop dan menyelaraskan antara materi dengan kegiatan praktikum yang ada disekolah.

Hal ini sejalan dengan kegiatan yang telah dilaksanakan oleh Suprapto dkk (2018) dan Arsyad (2010) yang menyatakan perlu adanya keselarasan materi yang ada sehingga akan menjadikan pemahaman peserta didik terhadap suatu materi menjadi lebih komprehensif dan konkret, sesuai dengan yang telah dikemukakan oleh Edgar Dale dalam "kerucut pengalaman (cone of experience) disimpulkan bahwa pengalaman langsung akan membuat pemahaman peserta didik lebih konkret.

Pendampingan pengenalan dan penggunaan operasional mikroskop dasar sangatlah penting guna pencapaian target tuntutan kurikulum nasional dan sekaligus membantu siswa/binaan membekali diri dalam meningkatkan kompetensi ilmu yang akan mereka dapatkan selama bangku sekolah dan mempersiapkan diri untuk mengikuti ujian akhir nasional nantinya. Untuk itu target kegiatan berupa transfer ilmu berupa pengenalan dan penggunaan mikroskop dasar sehingga peserta cakap cukup terampil dam pengoperasionalnya, serta mengenalkan berbagai macam bentuk sel dan jaringan makhluk hidup secara mikroskopis. Kegiatan ini merupakan kegiatan awal dari tujuan keseluruhan target tim pengabdi untuk selanjutnya dilakukan ke lokasi sekolah yang berbeda bukan saja binaan siswa melainkan para guru mata pelajaran IPA yang teridentifikasi cukup rendah dalam pemahaman terkait laboratorium.
Keterlaksanaan dan keberhasilan kegiatan ini dilaksanakan melalui 3 (tiga) metode pendekatan utama yaitu sosialisasi program, pemberian materi, dan pelatihan dan dalam akhir dilakukan evaluasi sebagai indikator capaian kegiatan.

Beberapa tahapan prosedur kerja untuk mendukung realisasi yang ditawarkan adalah:

1. Observasi awal yang dilakukan menggunakan teknik interview oleh guru bidang studi Biologi dan beberapa siswa kelas XI MA Annajah Yayasan Pendidikan Al-Halimy dan SMA Islam Al Azhar NW Kayangan sebagai calon binaan. Sedangkan calon binaan lainnya merupakan mahasiswa/I baru FPMIPA IKIP Mataram dilakukan dengan mengundang perwakilan untuk penentuan jadwal kegiatan.

2. Persiapan program meliputi penyusunan jadwal kegiatan yang disepakati bersama dan susunan acara pelatihan, dan menyiapkan perlengkapan penyelenggaraan pelatihan.

3. Rapat pemantapan materi dan pengecekan kebutuhan kegiatan bersama tim pengabdi.

4. Pemberian materi tentang dunia sel dan jaringan makhluk hidup dan penjelasan pengenalan dan teknis operasional penggunaan mikroskop yang dilakukan oleh tim peneliti.

5. Simulasi prosedur penggunaan mikroskop dasar

6. Tahap Evaluasi dengan pemberian angket respon keinginan binaan terhadap kegiatan yang dilaksnakan dengan indikator keberhasilan (dikembangan dari Senam, dkk.,2008; Nofisulastri dkk, 2013), yaitu persentase kebermanfaatan, termotivasi, dan keterkaitan ilmu yang diperoleh dari kegiatan yang dilaksanakan. 
Kegiatan pengabdian kepada masyarakat bertajuk pelatihan dan pendampingan operasional mikroskop dasar telah dilaksanakan mulai tanggal 19 sampai 27 April 2019 di Lboratorium Biologi FPMIPA IKIP Mataram.. Pelaksanaan kegiatan pengabdian masyarakat ini diawali survei lokasi sekaligus diskusi penjadwalan. Berdasarkan hasil kesepakatan dengan mitra dan calon binaan untuk dilaksanakan pada hari yang berbeda dengan turutan prosedur kegiatan yang sama (disajikan pada Gambar 1).

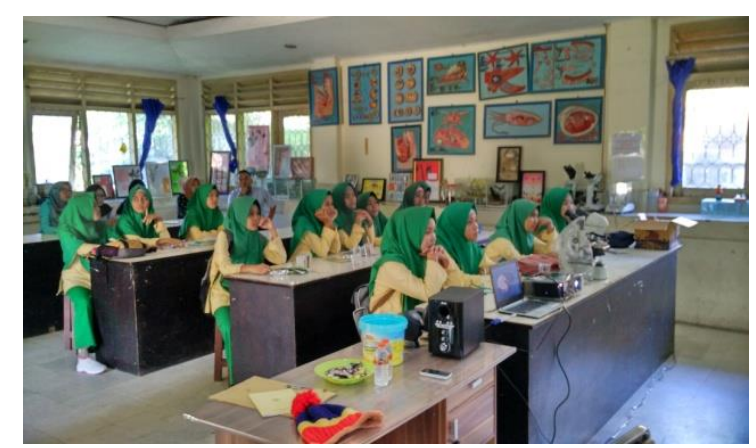

Gambar 1. Penayangan Video Profil IKIP Matam

Pelaksanaan kegiatan pengabdian tahap pertama dilaksanakan hari minggu (19/4/2019) pukul 09.00 - 11.00 Wita dengan peserta kegiatan adalah siswa/i kelas XI MA Annajah Yayasan Pendidikan Al-Halimy dan SMA Islam Al Azhar NW Kayangan. Sedangkan peserta kegiatan mahasiswa/i baru FPMIPA IKIP Mataram dilaksanakan pada pada hari sabtu (27/4/2019) pukul 13.00 - 14.30 Wita. Keseluruhan prosesi kegiatan disajikan pada Gambar 2 sebagai gambaran umum ter;aksananya kegiatan pengabdian masyarakat ini. Kegiatan diawali registrasi, sambutan tim pengabdi, penayangan video profil IKIP Mataram sebagai bagian strategi teknis promosi, pemberian materi umum terkait dunia sel dan jaringan oleh Siti Rabiatul Adawiyah, M.Pd dan dilanjutkkan materi pengenalan mikroskop sekaligus penanggung jawab dalam simulasi teknis mikroskop oleh Nofisulastri, M.Si .

Simulasi kegiatan diiringi diskusi dan tanya jawab peserta guna melihat seberapa jauh kesiapan peserta setelah pemberian materi. Prosesi ini diselesaikan hingga peserta kegiatan menyatakan jelas dan siap untuk ke tahapan selanjutnya. Tahapan pendampingan penggunaan mikroskop dibantu oleh 4-6 orang mahasiswa program studi Pendidikan Biologi FPMIPA IKIP Mataram berstatus asisten laboratoriom yang sebelumnya telah dipersiapkan dan terbina oleh tim pengabdi.

Bentuk pendampingan dilakukan secara berkelompok dimana masing kelompok (4-5 orang) diberikaan 3 jenis mikroskop yang berbeda dan preparat awetan sel dan jaringann. Secara teknis tim mahasiswa pendamping membantu dan bertanggung jawab masing-masing kelompok sedangkan tim pengabdi secara bergiliran mendampingi sekaligus member pelayanan penjelasan apabila peserta bertanya (Gambar 2).

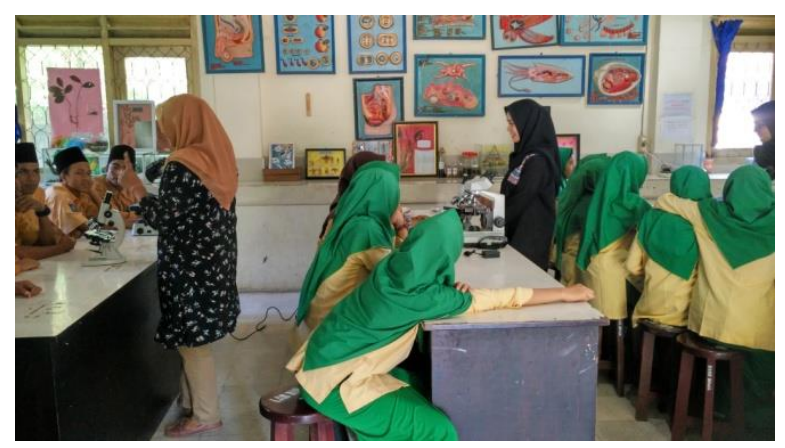

Gambar 2. Pendampingan Simulasi Operasional Tahap I

Masing-masing peserta kegiatan dipastikan oleh tim telah bergantian dan terampil menggunakan mikroskop dan dinyatakan selesai apabila seluruh peserta telah mampu menguasai dalam operasional mikroskop tersebut. Kegiatan ini semula dijadwalkan selama 1 jam namun dalam pelaksanaan menunjukkan waktu 1,5 jam dimana peserta cukup 
berantusias menggunakan mikroskop dan melihat tampilan preparat awetan yang dari imformasi berupa teori dan tayangan gambar/video yang diperoleh selama proses belajar.

Kegiatan berakhir dengan pengisian angket respon kegiatan berisikan ketertarikan, tingkat kesukaan dan kepuasan, kebermanfaatan ilmu yang ditransfer, dan ketertarikan peserta untuk mengikuti kegiatan selanjutnya atau sejenis (Gambar 3).

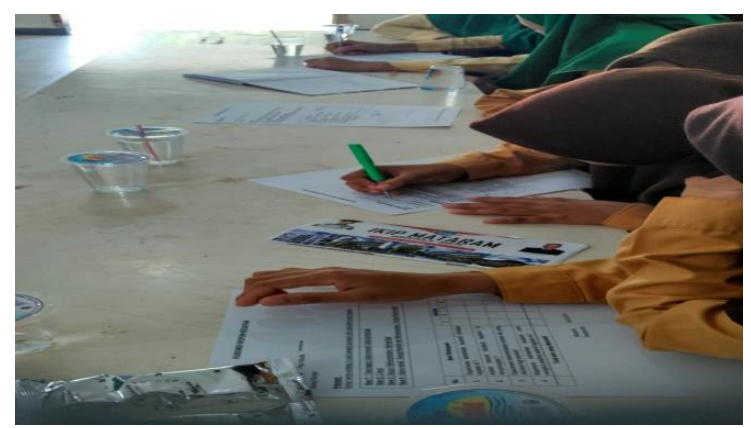

Gambar 3. Pengisian angket respon kegiatan

Penyebaran angket dilakukan sebanyak 30 lembar yang diberikan secara acak kepada peserta didampingi tim apabila peserta meminta penjelasan terhadap tujuan dan teknis pengsian angket. Hasil rekapitulasi respon kegiatan menunjukkan bahwa ketertarikan terhadap kegiatan sebesar 97\% berkategori menarik dan menyenangkan, kebermanfaatan ilmu senilai $90 \%$ dan ketertarikan untuk mengikuti kegiatan sejenis sebesar $98 \%$.

\section{KESIMPULAN}

Keberhasilan terukur terlihat dari hasil repon kegiatan lebih dari $90 \%$ kehadiran peserta datang tepat waktu dan responsive terhadap kebermanfaatan kegiatan terukur sangat bagus, adanya perpanjangan waktu yang diminta oleh peserta serta adanya harapan keberlanjutan pelatihan bagi siswa/l dan guru IPA MA Annajah Yayasan Pendidikan Al-Halimy dan SMA Islam Al Azhar NW Kayangan. Selain itu, selama kegiatan tidak diketemukan kendala teknis sehingga keseluruhan dinyatakan berjalan lancar.

\section{DAFTAR PUSTAKA}

Arsyad, A. 2010. Media Pembelajaran. Jakarta: PT. Rajagrafindo Persada.

Nofisulastri, Primawati S., Jannah H.,2014. Pembinaan Pembuatan Mie Kering SABU di Desa Jenggik Utara Kabupaten Lombok Timur. Laporan Akhir. Kegiatan Pengabdian Masyarakat DP2M DIKTI, Mataram.

Suprapto P.K., Ali M., Nuryadin E., 2018. Pelatihan Penggunaan dan Pemeliharaan Mikroskop bagi Guruguru Ipa Madrasah Tsanawiyah (MTs) di Wilayah Kabupaten Tasikmalaya. Jurnal Pengabdian Siliwangi, 4(1): 2330. 